Vol. 07 No. 02 Juli

p-ISSN 2339-1502

e-ISSN 2723-1070

\title{
ANALISIS DU PONT DALAM MENGUKUR NILAI INVESTASI DAN EFEKTIVITAS ORGANISASI PADA PT. ULTRAJAYA MILK INDUSTRY AND TRADING COMPANY TBK PERIODE 2016-2019
}

\author{
Kuspita Sari $^{1}$, Mari Fahtul Nur Fatimah ${ }^{2 *}$, Sylvia Oktaviani ${ }^{3}$ \\ Prodi Akuntansi, FEB Universitas Muhammadiyah Riau, Pekanbaru \\ *Email: Marifahtulnurfatimah@gmail.com
}

\begin{abstract}
ABSTRAK
Tujuan dari penelitian ini adalah mengetahui pengaruh analisis du pont terhadap nilai investasi dan efektivitas operasional pada PT. Ultrajaya Milk Industry and Trading Company Tbk periode 2016-2019. Penelitian ini menggunakan data sekunder yaitu laporan keuangan tahunan PT. Ultrajaya Milk Industry and Trading Company Tbk periode 2016-2019 dan di analisis menggunakan metode du pont. Hasil penelitian menunjukkan bahwa analisis du pont yang dilakukan di perusahaan dapat menjadi tolak ukur bagi investor yang ingin berinvestasi di perusahaan dan efektivitas organisasi perusahaan. Hal ini dikarenakan terjadi penurunan pengembalian investasi yang berpengaruh pada pertimbangan investor untuk berinvestasi di perusahaan. Untuk meningkatkan pengembalian investasi tersebut, perusahaan harus menerapkan efektivitas operasional untuk mengukur keberhasilan suatu perusahaan dalam mencapai tujuannya.
\end{abstract}

Kata kunci: Analisis Du Pont, Investasi, Efektivitas Organisasi

\begin{abstract}
The purpose of this study was to determine the effect of du pont analysis on investment and operational effectiveness at PT. Ultrajaya Milk Industry and Trading Company Tbk period 2016-2019. This study uses secondary data, namely the annual financial statements of PT. Ultrajaya Milk Industry and Trading Company Tbk period 20162019 and analyzed using the du pont method. The results show that the du pont analysis conducted in the company can be a benchmark for investors who want to invest in the company and the company's organizational effectiveness. This is due to a decrease in return on investment which affects the consideration of investors to invest in the company. To increase the return on investment, companies must implement operational effectiveness to measure the success of a company in achieving its goals.
\end{abstract}

Keywords: Du Pont Analysis, Investment, Organizational Effectiveness

\section{PENDAHULUAN}

Perkembangan dunia dalam perekonomian semakin berkembang pesat, banyaknya perusahaan-perusahaan diseluruh dunia saling berlomba-lomba untuk mendorong perusahaan mereka lebih efisien dan efektivitas agar lebih kompetitif karena perusahaan yang unggul dan kompetitiflah yang mampu bertahan dalam persaingan dunia usaha yang semakin ketat. Sehingga mendorong perusahaan untuk lebih efisien dan lebih selektif dalam beroperasi untuk mencapai dan meningkatkan kemampuan dalam menghasilkan keuntungan. Dalam dunia persaingan bisnis, perusahaan dituntut untuk mampu menganalisis kinerja dari perusahaannya. Kinerja perusahaan itu sendiri dapat mencakup kinerja keuangan maupun kinerja non keuangan 
(Azmi and Harti 2021; Lubis, Azmi, and Suriyanti 2019). Kemampuan ini berguna untuk menilai sejauh mana kekuatan dan peningkatan yang harus dilakukan oleh perusahaan untuk mengatur bisnis yang sedang dijalani. Untuk meningkatkan keuntungan di perusahaan, maka perusahaan membutuhkan investor untuk berinvestasi yang berperan sebagai penunjang bisnis untuk mengembangkan usaha yang dimiliki.

Investasi merupakan aktifitas menanamkan sejumlah dana agar dana tersebut dapat dikembangkan dalam jangka waktu yang telah ditentukan di masa depan untuk memperoleh keuntungan. Semakin banyak investor dalam suatu perusahaan maka hal ini menunjukkan bahwa perusahaan aman dan stabil untuk dijadikan tempat berinvestasi. Apabila investasi yang dilakukan investor memberikan tingkat pengembalian yang tinggi tentunya tinggi rendahnya risiko dipengaruhi oleh faktor ekonomi serta kondisi perusahaan. Investasi adalah salah satu cara yang digunakan dalam meningkatkan keuntungan perusahaan. Dalam memulai investasi di perusahaan, ada banyak pertimbangan yang harus dilakukan oleh investor. Salah satunya ialah menganalisis pengembalian investasi yang dimiliki perusahaan tersebut.

Pengembalian investasi atau return on investment (ROI) adalah rasio yang menunjukkan hasil dari jumlah aktiva yang digunakan dalam perusahaan atau suatu ukuran tentang efisieni manajemen. Rasio ini menunjukkan hasil dari seluruh aktiva yang dikendalikan dengan mengabaikan sumber pendanaan, rasio ini biasanya diukur dengan persentase. Analisis ROI digunakan untuk mengukur efisiensi yang dilakukan oleh masing-masing divisi di perusahaan dengan mengalokasikan biaya dan modal ke dalam divisi tersebut. Perhitungan ROI dapat membantu investor untuk mempertimbangkan kembali rencana investasi suatu aset. Apabila nilainya positif, maka hal ini merupakan pertanda baik. Artinya, investasi yang direncanakan bisa memberikan laba atau setidaknya mengembalikan biaya investasi yang telah dikeluarkan. Namun apabila hasil perhitungannya negatif, maka investor akan sangat mempertimbangkan hal ini karena investasi tersebut akan menimbulkan risiko kerugian. Analisis ROI juga digunakan untuk mengukur profitabilitas dari produk yang dihasilkan perusahaan. Selain itu, investor juga harus menganalisis du pont pada perusahaan yang bersangkutan. 
Analisis $d u$ pont bersifat menyeluruh karena mencakup tingkat efisiensi perusahaan dalam menggunakan aktivanya dan dapat mengukur tingkat keuntungan atas penjualan produk yang dihasilkan oleh perusahaan tersebut. Untuk melihat dan menilai tingkat efektivitas operasional suatu perusahaan, tidak hanya menggunakan kepekaan dan ketajaman para manajer secara kualitatif saja, tetapi harus menggunakan metode secara kuantitatif Analisis du pont juga merupakan suatu metode yang digunakan untuk menilai efektivitas operasional perusahaan karena dalam analisis ini mencakup unsur penjualan, aktiva, dan laba yang dihasilkan perusahaan. Efektivitas operasional merupakan hal terpenting karena merupakan point utama dalam menghadapi persaingan bisnis.

Analisis du pont digunakan untuk mengetahui faktor mana yang paling kuat pengaruhnya antara profit margin dan total asset turnover terhadap ROI. Analisis du pont dapat membantu perusahaan untuk melihat bagaimana keputusan-keputusan perusahaan dan aktivitasnya sepanjang periode akuntansi yang diukur dengan rasio-rasio keuangan. Dengan menggunakan analisis ini, pengendalian biaya dapat diukur dan efisiensi perputaran aktiva sebagai akibat turun naiknya penjualan dapat diukur(Lestari and Dziqron 2014). Berdasarkan latar belakang diatas, maka peneliti mengambil judul “ Pengaruh Analisis Du Pont terhadap Pengukuran Nilai Investasi dan Efektivitas Organisasi pada PT. Ultrajaya Milk Trading and Company Tbk"

\section{TINJAUAN PUSTAKA}

\section{Analisis Du Pont}

Analisis $d u$ pont adalah rasio keuangan yang digunakan untuk menganalisis kemampuan perusahaan untuk meningkatkan pengembalian atas ekuitas atau return on equity (ROE). Return on equity (ROE) mengukur kemampuan perusahaan menghasilkan laba bersih berdasarkan modal tertentu. Kenaikan rasio ini berarti terjadi kenaikan laba bersih dari perusahaan yang bersangkutan. Jadi, para investor dapat menggunakan indikator ROE sebagai bahan pertimbangan dalam memilih saham atau menanamkan modalnya, karena rasio ini menunjukkan bahwa dengan kinerja manajemen dapat meningkat maka perusahaan dapat mengelola sumber dana pembiayaan operasional secara efektif untuk menghasilkan laba bersih sehingga saham perusahaan banyak diminati investor(Husaini 2012). 
Analisis du pont merupakan alat analisis yang digunakan untuk menganalisis laba dari perusahaan atau bisnis. Analisis Du Pont System adalah return on equity (ROE) yang dihasilkan melalui perkalian antara keuntungan dari komponen-komponen sales serta efisiensi penggunaan total assets di dalam menghasilkan keuntungan tersebut (Datum and Widianti 2015). Ada dua perhitungan dalam analisis du pont yaitu return on invesment (ROI) dan retained earning (RE). Berikut cara perhitungan return on invesment (ROI) dalam metode du pont, yaitu:

\section{ROI = NPM x Perputaran Total Aktiva}

Keterangan:

- $\quad$ Net profit margin $(\mathrm{NPM})=$ Laba bersih/total pendapatan $\mathrm{x} 100$

- Perputaran total aktiva $=$ Penjualan bersih tahunan/rata-rata total aset tahunan Sedangkan perhitungan retained earning (RE) dalam metode du pont yaitu:

\section{$\mathrm{RE}=$ Profit Margin $\times$ Perputaran Total Aktiva}

Keterangan:

- $\quad$ Profit Margin = Laba bersih/Penjualan bersih

- Perputaran total aktiva $=$ Penjualan bersih tahunan/rata-rata total aset tahunan

Du pont dirancang untuk menunjukkan hubungan antara pengembalian atas aktiva, perputaran aktiva marjin laba dan leverage (Dewi Astuti, 2004). Analisis keuangan sistem du pont memberikan suatu kerangka analisis yang menghubungkan berbagai macam rasio. Dalam analisis ini, rasio profitabilitas, rasio laverage, dan rasio efisiensi digabungkan untuk mendapatkan rasio return on net worth. Return on net worth adalah rasio untuk mengukur kemampuan modal sendiri diinvestasikan dalam menghasilkan pendapatan bagi pemegang saham. Analisis du pont mencakup rasio aktivitas dan margin keuntungan atas penjualan untuk menentukan profitabilitas yang dimiliki perusahaan. Menurut (Munawir, 2019:91) manfaat dari analisis Du Pont System adalah sebagai efisiensi produk dan penjualan, pengukuran profitabilitas dari produk yang diperoleh, pengukuran efisiensi modal kerja. Dapat melakukan 
sesuatu perbandingan efisiensi modal perusahaan satu dengan perusahaan sejenis, serta perencanaan ROI terhadap proyeksi penjualan.

\section{Investasi}

Investasi menurut Ahmad (20014:3) dalam Wulandari, Rahayu dan Nuzula, investasi adalah menempatkan uang atau dana dengan harapan untuk memperoleh tambahan atau keuntungan tertentu atas uang atau dana tersebut. investasi adalah komitmen atas sejumlah dana atau sumber daya lainnya yang dilakukan pada saat ini, dengan tujuan memperoleh sejumlah keuntungan di masa datang(Wulandari, Rahayu, and Nuzula 2016). Dalam menjalankan operasi perusahaan, manajemen menghendaki kas atau aset lain yang tidak dibutuhkan dalam jangka waktu dekat, diinvestasikan dengan cara yang menguntungkan dalam berbagai surat berharga atau aset penghasil laba lainnya.

Investasi berarti pengeluaran dana saat ini dengan harapan memperoleh hasil atau keuntungan dimasa yang akan datang (Wiagustini, 2014) dalam Normal (2017). Dilihat dari dimensi waktu, investasi dapat dikelompokkan menjadi dua, yaitu (1) Investasi jangka pendek (satu tahun atau kurang), yaitu investasi pada aktiva lancar (modal kerja), seperti: kas, piutang, investor, surat-surat berharga; dan (2) Investasi jangka panjang (lebih dari satu tahun), yaitu: investasi pada asset riil, seperti: tanah, bangunan, peralatan, kantor, kendaraan, asset riil lainnya, dan investasi pada asset finansial, seperti: investasi pada saham dan obligasi (Normal 2017). Pihak yang melakukan kegiatan investasi disebut dengan investor.

Menurut Sadono Sukirno (2000) kegiatan investasi memungkinkan suatu masyarakat terus menerus meningkatkan kegiatan ekonomi dan kesempatan kerja, meningkatkan pendapatan nasional dan meningkatkan taraf kemakmuran masyarakat. Peranan ini bersumber dari tiga fungsi penting dari kegiatan investasi, yakni (1) investasi merupakan salah satu komponen dari pengeluaran agregat, sehingga kanaikan investasi akan meningkatkan permintaan agregat, sehingga kenaikan investasi akan meningkatkan permintaan agregat, pendapatan nasional serta kesemapatan kerja; (2) pertambahan barang modal sebagai akibat investasi akan menambahkan kapasitas produksi; (3) investasi selalu diikuti oleh perkembangan teknologi. 
Investor digolongkan menjadi dua yaitu investor individual dan investor institusional. Investor individual terdiri dari perseorangan yang melakukan aktifitas investasi. Sedangkan investor institusional terdiri dari perusahaan-perusahaan asuransi, lembaga penyimpan dana, lembaga dana pensiun maupun perusahaan investasi. Lembaga ini biasanya mengumpulkan uang dari nasabah untuk menggunakan uang itu sebagai modal investasi di perusahaan atau dibelikan obligasi maupun saham. Kesejahteraan investor berarti kesejahteraan yang sifatnya moneter. Kesejahteraan moneter dapat ditunjukkan dengan jumlah pendapatan yang dimiliki saat ini dan nilai saat ini (present value) pendapatan diperoleh dimasa yang akan datang.

Salah satu dasar keputusan investor dalam berinvestasi ialah tingkat return yang diharapkan. Return yang diharapkan merupakan kompensasi atas kesempatan dan risiko penurunan daya beli akibat adanya pengaruh inflasi. Dalam konteks manajemen investasi, ada return yang diharapkan (expected return) dan return yang terjadi (realized return). Return yang diharapkan merupakan tingkat return yang diantisipasi investor di masa yang akan datang. Sedangkan return yang terjadi adalah return yang telah diterima oleh investor. Dalam berinvestasi, investor harus mempertimbangkan tingkat risiko investasi tersebut. Semakin besar risiko yang diambil oleh investor maka semakin besar pula tingkat return yang diharapkan.

\section{Efektivitas Organisasi}

Efektivitas organisasi tingkat ketepatan atau keberhasilan organisasi dalam mencapai tujuan yang sama antara pimpinan dan karyawan guna memenuhi kebutuhan bersama. Efektivitas organisasi merupakan kontribusi hasil kerja dari tiap-tiap efektivitas individu dan efektivitas kelompok/tim yang saling sinergis. Menurut Campbel kriteria ukuran efektivitas organisasi seharusnya dikembangkan untuk (1) membandingkan organisasi satu dengan organisasi lainnya. Suatu organisasi yang menggunakan sumberdaya yang sama tetapi menghasilkan keuntungan yang berbeda, bisa dikatakan bahwa organisasi yang satu lebih efektif dibandingkan organisasi yang lain. (2) mengevaluasi akibat usaha pengembangan organisasi. Pengembangan organisasi yang tidak menghasilkan nilai tambah menunjukkan kegiatan yang telah dilakukan tersebut tidak efektif. (3) Menentukan karakteristik apa yang secara signifikan dapat dihubungkan dengan efektivitas organisasi (Campbell, 1977). 
Efektivitas organisasi sangat dipengaruhi oleh sumber daya manusia yang ada di perusahaan. Kinerja organisasi tergantung kinerja individu. Manajer dan pimpinan harus mempunyai kemampuan yang lebih dalam hal penentuan kinerja individu. Kepemimpinan salah satu faktor yang mempengaruhi karena pemimpin memberikan pengaruh dan menggerakkan seluruh anggota agar bekerja sama untuk mencapai tujuan organisasi. Faktorfaktor yang mempengaruhi efektivitas kerja dalam perusahaan ialah motivasi kerja individu, kemampuan kerja individu, suasana kerja, lingkungan kerja, dan prosedur kerja yang diterapkan organisasi kepada individunya.

Robbins (1996:3) mengemukakan empat fungsi manajemen yang berpengaruh terhadap efektivitas organisasi, yaitu perencanaan, pengorganisasian, kepemimpinan dan pengendalian. Perencanaan mencakup penetapan tujuan, penegakan strategi dan pengembangan rencana untuk mengkoordinasikan kegiatan. Pengorganisasian mencakup penetapan tugas-tugas apa yang harus dikerjakan, siapa yang harus mengerjakan, bagaimana tugas-tugas itu dikelompokkan, siapa melapor kepada siapa dan dimana keputusan harus diambil. Kepemimpinan mencakup hal motivasi bawahan, mengarahkan orang lain, menyeleksi saluran-saluran komunikasi yang paling efektif, dan memecahkan konflik-konflik. Pengendalian merupakan kegiatan-kegiatan untuk memastikan kegiatan itu dicapai sesuai dengan yang direncanakan dan mengoreksi setiap penyimpangan yang terjadi.

Ada enam jenis keputusan di mana data tentang kriteria organisasi bisa digunakan, yang terdiri dari masalah praktis dalam organisasi dan upaya untuk memahami bagaimana organisasi beroperasi, yaitu:

1) Memutuskan apakah aspek suatu sistem adalah baik atau jelek. Turnover, profitabilitas atau return on investment, frekuensi kecelakaan adalah salah satu cara untuk menilai sistem organisasi baik ataukah jelek.

2) Menentukan mengapa suatu sistem harus demikian. Apa yang menyebabkan turnover tinggi, mengapa profitabilitas naik atau turun, mengapa sering terjadi kecelakaan? 
3) Perencanaan harus dibuat sesuai dengan tindakan yang seharusnya diambil untuk mengubah sistem. Apa yang harus dilakukan untuk menurunkan turnover atau menurunkan frekuensi kecelakaan?

4) Perbandingan organisasi diperlukan untuk pengambilan keputusan publik. Aturan pemerintah akan mempengaruhi organisasi dan membandingkannya dengan organisasi lain. Misalnya aturan tentang upah minimum harian, tunjangan lembur dan sebagainya.

5) Organisasi menggunakan ukuran efektivitas untuk mengevaluasi usaha pengembangan organisasi.

6) Pembuatan ranking organisasi berdasarkan ukuran efektivitas untuk mempelajari penyebab efektivitas dalam organisasi.

\section{METODE PENELITIAN}

\section{Jenis Penelitian}

Jenis penelitian ini menggunakan penelitian kualitatif deskriptif dengan menggunakan metode analisis du pont. Menurut Winartha (2006), metode analisis deskriptif kualitatif adalah menganalisis, menggambarkan, dan meringkas berbagai kondisi, situasi dari berbagai data yang dikumpulkan berupa hasil wawacara atau pengamatan mengnai masalah yang diteliti yang terjadi di lapangan.

\section{Teknik Pengumpulan dan Analisis Data}

Data yang digunakan adalah data kualitatif yang diperoleh dari laporan keuangan PT. Ultrajaya Milk Industry and Trading Company Tbk periode 2016-2019. Teknik pengumpulan data yang digunakan dalam penelitian ini adalah sumber data sekunder. Sumber data ini diperoleh dari data laporan tahunan PT. Ultrajaya Milk Trading and Company Tbk yang terdaftar di Bursa Efek Indonesia dan Situs Resmi PT. Ultrajaya Milk Industry and Trading Company Tbk periode 2016-2019. Teknik analisis data yang digunakan peneliti adalah metode analisis du pont dan menggunakan analisis deskriptif karena peneliti menggunakan tabel dan grafik untuk menjelaskan hasil dari penelitian tersebut. 


\section{HASIL DAN PEMBAHASAN}

Tabel 1. Hasil perhitungan Analisis Du Pont ( Return on Investment)

\begin{tabular}{|l|l|l|l|}
\hline Periode & NPM & Perputaran Total Aktiva & ROI \\
\hline 2016 & $789.825 .635 / 4.685 .987 \times 100 \%=16,86 \%$ & $4.685 .987 / 4.239 .199=1,11$ & $18,7 \%$ \\
\hline 2017 & $711.681 .000 / 4.879 .559 \times 100 \%=14,58 \%$ & $4.879 .559 / 5.186 .940=0,94$ & $13,7 \%$ \\
\hline 2018 & $701.607 .000 / 5.472 .882 \times 100 \%=12,81 \%$ & $5.472 .882 / 5.555 .871=0,98$ & $12,6 \%$ \\
\hline 2019 & $1.035 .865 / 6.241 .419 \times 100 \%=16,6 \%$ & $6.241 .419 / 6.608 .422=0,94$ & $15,6 \%$ \\
\hline
\end{tabular}

Sumber: data olahan

\section{ROI}

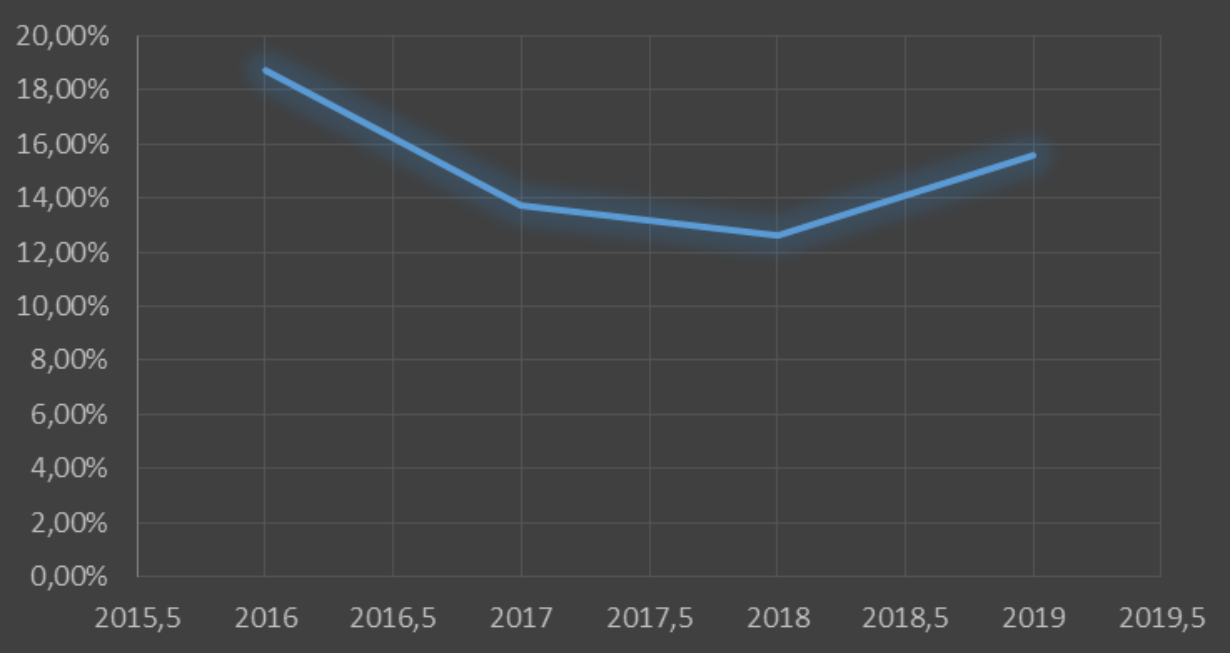

Gambar 1 Grafik Return On Investment

Berdasarkan hasil perhitungan di atas, persentase pada tahun 2016 merupakan persentase tertinggi yaitu $18,7 \%$ selama 4 tahun periode dari tahun 2016-2019. Hal ini menunjukkan bahwa semakin besar net profit margin maka semakin baik perusahaan mengonversi pendapatan menjadi laba bersih. Apabila persentase ROI semakin tinggi maka nilai suatu investasi atau biaya peluang yang diberikan investor untuk berinvestasi di 
perusahaan juga semakin bagus. Namun terjadi perununan persentase pada tahun 2017 sebesar 13,7\% dan menurun jauh pada tahun 2018 sebesar 12,6\%. Penurunan ROI pada tahun 2017 dan 2018 mengindikasikan bahwa kemampuan manajemen menurun dalam melaksanakan pengelolaan seluruh aktivanya untuk menghasilkan laba operasi bersih. Penurunan persentase ini membuat pemimpin dan manajer berusaha untuk memotivasi kinerja karyawan agar dapat meningkatkan pendapatan. Sehingga pada tahun 2019 nilai persentase meningkat menjadi 15,6\%. Hal ini merupakan berita baik bagi investor yang ingin berinvestasi di perusahaan. Dengan meningkatnya persentase ROI pada tahun 2019, manajemen pengelolaan aktiva dianggap berhasil karena dapat meningkatkan laba bersih dibandingkan pada tahun sebelumnya dan nilai investasi perusahaan juga akan dianggap baik oleh investor

Tabel hasil 2. Perhitungan Analisis Du Pont (Retained Earning)

\begin{tabular}{|l|l|l|l|}
\hline Periode & PM = Laba usaha/ PJ × 100\% & $\begin{array}{l}\text { Perputaran Total } \\
\text { Aktiva }\end{array}$ & RE \\
\hline 2016 & $888.986 / 4.685 .987 \times 100 \%=18,97 \%$ & 1,11 & $21,06 \%$ \\
\hline 2017 & $959.334 / 4.879 .559 \times 100 \%=19,66 \%$ & 0,94 & $18,48 \%$ \\
\hline 2018 & $892.565 / 5.472 .882 \times 100 \%=16,30 \%$ & 0,98 & $15,97 \%$ \\
\hline 2019 & $1.264 .394 / 6.241 .419 \times 100 \%=20,26 \%$ & 0,94 & $19 \%$ \\
\hline
\end{tabular}

Sumber: data olahan

\section{RE}

\section{$25,00 \%$}

$20,00 \%$

$15,00 \%$

$10,00 \%$

$5,00 \%$

$0,00 \%$

$\begin{array}{lllllllll}2015,5 & 2016 & 2016,5 & 2017 & 2017,5 & 2018 & 2018,5 & 2019 & 2019,5\end{array}$




\section{Gambar 2 Grafik Retained Earning}

Berdasarkan hasil perhitungan di atas, persentase tahun 2016 merupakan persentase tertinggi selama periode 2016-2019 yaitu sebesar 21\%. Hal ini menunjukkan bahwa pada tahun 2016 perusahaan mempunyai kesiapan dana untuk keperluan investasi. Namun pada tahun 2017 dan 2018 terjadi penurunan laba ditahan. Laba usaha dan penjualan yang menurun pada tahun 2017 dan 2018 membuat persentase laba ditahan ikut menurun. Hal ini membuat perusahaan mengalami kendala dalam membayar utang perusahaan maupun pengembangan investasi karena cadangan keuangan yang mereka miliki menurun selama dua tahun berturutturut. Pada tahun berikutnya yaitu pada tahun 2019, terjadi peningkatan laba usaha dan penjualan yang memacu peningkatan persentase retained earning menjadi 19\%. Semakin besar jumlah laba ditahan maka sehat pula perusahaan dari segi keuangan. Terjadinya peningkatan laba ditahan pada tahun 2019 dapat dijadikan investasi perusahaan untuk kelangsungan pertumbuhan perusahaan.

\section{PENUTUP}

Berdasarkan hasil penelitian diatas, maka dapat ditarik kesimpulan sebagai berikut:

1. Hasil perhitungan return on investment (ROI) mengalami kenaikan dan penurunan selama 4 tahun. Penurunan persentase ROI terjadi pada tahun 2017 sebesar 13,9\% dan tahun 2018 kembali menurun sebesar 12,16\%. Penurunan ini dapat berisiko terhadap investasi perusahaan karena ROI salah satu faktor pertimbangan investor dalam nerinvestasi di perusahaan. Dan pada tahun 2019 nilai persentase meningkat menjadi 15,6\%, dengan demikian perusahaan dapat memperbaiki kembali kekurangan ditahun sebelumnya dengan memotivasi kinerja kerja agar dapat meningkatkan pendapatan dan laba bersih.

2. Hasil perhitungan retained earning, mengalami penurunan selama 4 tahun. Persentase dari tahun 2016-2019 mengalami penurunun dengan total 2,06\%. Hal ini menunjukkan saldo laba yang dimiliki perusahaan semakin menurun. Namun diibandingkan dengan tahun 2017 dan 2018, pada tahun 2019 mengalami peningkatkan kembali. Hal ini menunjukkan bahwa peningkatan laba ditahan pada tahun 2019 menggambarkan cadangan keuangan perusahaan semakin membaik dari tahun sebelumnya. 


\section{DAFTAR PUSTAKA}

Azmi, Zul, and Isra Desmi Harti. 2021. "Pengaruh Akuntansi Manajemen Strategik Dan Kapabilitas Organisasional Terhadap Kinerja Organisasi." Ekonomis: Journal of Economics and Business 5(1): 266.

Datum, Nasyiatul Mumtaz, and Hesti Widianti. "Analisis Sistem Du-Pont Untuk Mengukur Kinerja Keuangan Perusahaan Pada Cv. Astamedika Tegal." Akuntansi Politeknik Harapan Bersama (09): 62-67.

Husaini, Achmad. 2012. "Pengaruh Variabel Return On Assets, Return On Equity, Net Profit Margin Dan Earning Per Share Terhadap Harga Saham Perusahaan." Jurnal Administrasi Bisnis 6(1): 45-49.

Lestari, Wuryaningsih Dwi, and Moh Dziqron. 2014. "PENERAPAN DU PONT SYSTEM UNTUK MENGUKUR KINERJA KEUANGAN PERUSAHAAN ( Studi Pada Perusahaan Semen Yang Terdaftar Di BEI Tahun 2007-2011 ).” (Sancall): 327-41.

Lubis, Putriinti Amelia, Zul Azmi, and Linda Hetri Suriyanti. 2019. "Pengaruh Customer Accounting Dan Customer Orientation Terhadap Kinerja Organisasi." Jurnal Al-Iqtishad 15(2): 180-215.

Normal, I Nyoman. 2017. "Kinerja Investasi Jasa Pengujian Tableware Untuk Produk Kreatif Keramik Pada Btikk-Bppt.” Jurnal Keuangan dan Perbankan 21(1): 47-59.

Wulandari, O., S. Rahayu, and N. Nuzula. 2016. “ANALISIS FUNDAMENTAL MENGGUNAKAN PENDEKATAN PRICE EARNINGS RATIO UNTUK MENILAI HARGA INTRINSIK SAHAM UNTUK PENGAMBILAN KEPUTUSAN INVESTASI SAHAM (Studi Pada Perusahaan Yang Sahamnya Masuk Indeks LQ45 Periode Tahun 2010-2012 Di Bursa Efek Indonesia)." Jurnal Administrasi Bisnis S1 Universitas Brawijaya 31(1): 73-80. 